Gender, Place \& Culture

A Journal of Feminist Geography

ISSN: 0966-369X (Print) 1360-0524 (Online) Journal homepage: http://www.tandfonline.com/loi/cgpc20

\title{
Ways of Seeing: Sexism the Forgotten Prejudice?
}

\section{Gill Valentine, Lucy Jackson \& Lucy Mayblin}

To cite this article: Gill Valentine, Lucy Jackson \& Lucy Mayblin (2014) Ways of Seeing: Sexism the Forgotten Prejudice?, Gender, Place \& Culture, 21:4, 401-414, DOI: 10.1080/0966369X.2014.913007

To link to this article: http://dx.doi.org/10.1080/0966369X.2014.913007

\section{(c) 2014 The Author(s). Published by Taylor \& Francis.}

\section{曲 Published online: 21 May 2014.}

Submit your article to this journal $\asymp$

\section{Џlll Article views: 3166}

Q View related articles $₫$

View Crossmark data \lceil

Citing articles: 22 View citing articles $\asymp$ 


\title{
21 YEARS OF GENDER, PLACE AND CULTURE
}

\section{Ways of seeing: sexism - the forgotten prejudice?}

\author{
Gill Valentine*, Lucy Jackson and Lucy Mayblin \\ Department of Geography, University of Sheffield, Winter Street, Sheffield S10 2TN, UK
}

(Received 10 January 2014; final version received 4 March 2014)

\begin{abstract}
Recent developments in feminism, charted in Gender, Place and Culture over the past 21 years, have stressed the relational, differentiated and contested nature of gender. This has led to the rejection of the unified category women, and with this the right for feminism to make claims on behalf of all women. This paper argues that an unintended consequence of this development in ways of thinking about gender is that patriarchy as a form of power relations has become relatively neglected. It draws on research from a European Research Council project (including biographical interviews and case studies of a gym and workplace) to demonstrate that while the development of equality legislation has contained the public expression of the most blatant forms of gender prejudice, sexism persists and is manifest in subtle ways. As a consequence, it can be difficult to name and challenge with the effect that patriarchy as a power structure which systematically (re)produces gender inequalities, is obscured by its ordinariness. Rather, sexism appears only to be 'seen' when it affords the instantiation of other forms of prejudice, such as Islamophobia. As such, we argue that Gender, Place and Culture has a responsibility going forward to make sexism as a particular form of prejudice more visible, while also exposing the complexity and fluidity of its intersectional relationship to other forms of oppression and social categories.
\end{abstract}

Keywords: gender; sexism; prejudice; intersection; seeing differently; patriarchy

\section{Introduction - sexism: the forgotten prejudice}

Shortly after Gender, Place and Culture was launched as a journal, Bunch (1995) argued that the fundamental basis of feminism is the body of the woman and the violence committed against it, given the universality of sexism, sexual harassment and rape. Yet, as research on gender and geography has evolved theoretically and empirically over the 21 years of Gender, Place and Culture's existence, such grand narratives of feminism have been largely rejected. So-called 'third wave' feminism has critiqued the assumption that women share a common gender identity and set of experiences. Rather, such universalist claims have been destabilised by recognition that what it means to be a woman is constituted through the intersection of gender with other social differences (Crenshaw 1989). Consequently, although social categories such as gender, race and class have commonly been analysed by geographers as separate social structures, it is now widely acknowledged that as individuals we experience and live them simultaneously (Valentine 2007).

This rejection of the unified category 'woman' has meant that the importance and understanding of systematic gender inequalities and patriarchy as an issue of power has diminished as the right to make group claims and act on the basis of shared experience has been lost. As such, some scholars have claimed that feminist politics has become more

*Corresponding author. Email: g.valentine@ sheffield.ac.uk 
diffuse, transitory and implicitly less effective (e.g. Johnson 1994, 2013), notwithstanding the blossoming of geographies of gender in Gender, Place and Culture - informed by post-structural and postcolonial theories - which have, and continue, to unpick the relational, differentiated and contested nature of 'gender' as lived and experienced (e.g. Staeheli and Nager 2002; Siraj 2011; Bailey and Shabazz 2013).

Indeed, general advances in women's position in the labour market in Europe, North America and Australasia over the last few decades have led to popular claims that feminism is less pertinent to younger generations of women, and by implication to suggest that sexism as a form of prejudice may be disappearing.

While there has been a recent proliferation of studies of racism, Islamophobia and homophobia including in Gender, Place and Culture (e.g. Bailey and Shabazz 2013; Phillips 2012; Muller 2007), sexism and gender hate as forms of discrimination and prejudice appear to have largely dropped off the geographical map. Yet, cursory attention to public life exposes the apparent persistence of sexism and gender hate crime, from the British Prime Minister David Cameron's banal put-down 'calm down dear' to a female opposition minister, to the repetitive misogynistic abuse of the Australian Prime Minister Julia Gillard (Mclean and Maalsen 2013) and violent rapes in India and Kenya which have bought thousands of people onto the streets in protest.

This paper draws on empirical material from a European Research Council funded study, Living with Difference, to reflect on sexism as a forgotten form of prejudice and to argue for the need for Gender, Place and Culture to make this form of power more visible in its next decade. The first section of this paper focuses on the ordinariness of everyday sexism, demonstrating that while the development of equality legislation has contained the public expression of the most blatant forms of gender prejudice, sexism persists and is manifest in subtle ways. The second section of the paper reflects on the (in)visibility of sexism, and the final section of the paper examines the intersection of sexism with Islamaphobia and class prejudice.

The evidence upon which the paper draws includes in-depth multi-stage qualitative research with individuals to explore lived experiences of social differentiation and studies of specific spaces to examine what kinds of socio-spatial encounter produce meaningful contact (i.e. contact that changes attitude beyond the specifics of the moment into a more general positive respect for, rather than merely tolerance of, others) (Valentine 2008). The Lived Experience element of the study involved case study work with 30 individuals. Each case comprised a timeline, a life-story interview, a semi-structured interview about understandings of and attitudes towards equality and diversity, and an interview reflecting on the emerging findings of the study ( $n=90$ interviews). The participants were recruited from amongst respondents to a survey about attitudes towards difference which was conducted in Leeds, UK $(n=1522)$ as part of the Living with Difference research programme. They were sampled to include those from a range of social backgrounds (in terms of socio-economic status, occupation, gender, ethnicity, religious/belief, sexual orientation and (dis)ability); whose personal circumstances and lifestyle afford them a range of opportunities for/experiences of encountering 'difference' and to reflect the range of responses to the survey.

The element of the study exploring specific sites of encounter involved two case studies: first, of a leisure space: a gym; and second of a workplace: a brigade in the fire and rescue service. The first case study comprised 25 individual semi-structured interviews with gym members ranging from 30 minutes to 1.5 hours, plus 123 hours of participant observation. Participants were male and female, ranged in age from 23 to 70 years and came from a range of socio-economic backgrounds. Here, the interviewees were questioned about their perceptions of diversity within the gym, particularly in relation to 
the surrounding neighbourhood, and the extent and nature of their encounters within the gym with people they considered to be different from themselves. The second case study comprised 25 individual semi-structured interviews with full-time firefighters ranging from 45 minutes to 2 hours. Participants were questioned about their experiences of diversity in the workplace in relation to a range of 'equality strands'. The majority of research participants were white, ranged from 26 to 52 years of age and were from similar socio-economic backgrounds, described by participants themselves as 'working class'. All the quotations included in this paper are verbatim. Three ellipsis dots are used to indicate minor edits have been made to clarify the readability of quotations. The phrase [edit] is used to signify a significant section of text has been removed. Any names referred to in the quotations are pseudonyms.

\section{The ordinariness of sexism: forgotten geographies of gendered segregation}

Spatial segregation has long been a key theme in urban and social geography, dating back to the work of the Chicago School of Human Ecology in the 1920s that used an analogy with plant ecology (including notions of 'invasion', 'succession') to understand sociospatial patterning within the city. The legacy of this work was a recognition of the sociospatial segregation of minority ethnic groups. Subsequently, research has gone on to explore the relationship between such patterns of segregation and discriminatory practices in housing and labour markets (e.g. Anderson 1991). More recently, research has focused on how changes in the provision of infrastructures for transport, communication and utilities as we transition to post-industrial society are producing a new form of spatial segregation - enclave urbanism. This research suggests that new forms of exclusion are being produced as the premium enclaves of the wealthy are well connected by new privatised infrastructures, those for the underprivileged are increasingly disconnected with the consequence that social interaction between groups is limited.

By contrast, the gendered nature of spatial segregation has not received such sustained attention. Early feminist geography recognised that the development of the nineteenthand twentieth-century western cities had led to a spatial separation of industry, commerce and political power in the public sphere, the domain of men. from the private realm of the home and social reproduction which became represented as the domain of women (WGSG 1984; McDowell 1983; Bondi and Rose 2003). This gendered division of space received much attention in the 1980s and 1990s. This included a body of work examining occupational segregation by gender (Hansen and Pratt 1995), including women's experiences of sexism and sexual harassment in jobs gendered as male (McDowell 1997, 2009), as well as work in this journal which has identified the way women's reproductive labour is mobilised to justify gender inequalities (Macleavy 2007). Likewise, there was recognition that women's use and occupation of public space was shaped by routine experiences of verbal abuse, sexual harassment and the threat of male violence (e.g. Valentine 1989, 1992; Pain 1991). Yet, over the last decade these issues have received diminishing attention. The physical and ideological separation of home and work has been eroded; women have made significant progress in the labour market; there has been a blurring of the distinction of public/private with the growth of home working; and the feminisation of the labour market has produced an associated growth in women's incomes: as documented in Gender, Place and Culture (e.g. Macleavy 2007). This has been paralleled with the development of night-time economies in post-industrial cities which have targeted women as consumers (Holloway, Valentine, and Jayne 2009), all of which have contributed to women's more confident occupation of public space (Koskela 1997). 
At the same time, the category 'woman' has been troubled by recognition of the complex and intersectional nature of identity (Valentine 2007). As a result, the gendered nature of everyday spaces appears to have slipped from the geographical agenda, becoming notably less common as the focus of articles published in Gender, Place and Culture.

The evidence of the research cited is that everyday spaces continue to be occupied and used in gendered ways. At the gym where we conducted case study research - with the exception of the changing rooms - the swimming pool, aerobics studios, equipment (treadmills, rowing machines, etc.) and weights areas are open to both sexes. The use of space, however, was highly structured along gender lines: a pattern also evident in Johnston's (1996) study of the experiences of female bodybuilders. Men dominated the gym and weights area, and women the classes, with limited mixing in the swimming pool area - while there were some exceptions, these only go to prove the rule as these interviewees describe:

$\ldots$ on this side [describing the layout of the gym] it's got a lot of weight machines and dumbbells ... sometimes when I've been in there I've felt quite like I shouldn't be in there because I'm a woman and all the men are there, really pumping iron. So you sometimes get a few looks if you're a woman going in there.

Interviewer: What kind of looks?

Just like ... why are you in here? Or what are you doing? Or things like that. Sometimes I do get that feeling in there ... I have gone in there sometimes because I want to use this machine. But you'll go in and there'll just be no women there, it's just men. So I get the feeling that most women don't like going in there .... (White British female, 20-24)

It's classes ... that is a woman's thing to do I don't know why the classes are a girls' thing. I don't really mind, I went on numerous occasions [to aerobics class] ... I think, even in my generation, I know loads of my male friends wouldn't go to a class. (White British male, $18-24)$

However, men who were interviewed in our research did not consider the gendered nature of the gym a problem, usually describing it in essentialised terms as 'natural': a product of choice because of the perceived different interests, and preferences of the sexes. In contrast, women interviewees described how their freedom to use the space of the gym was constrained by the behaviour of male gym members. In particular, women of all ages recounted being subject to the normalising judgement of the male gaze within the context of heteronormativity which has the disciplinary effect (after Foucault 1977) of causing them to self-regulate their bodies and use of space (cf. Bartky 1990; Johnston 1996). As Young (1990) has argued in her seminal essay, Throwing Like a Girl, the patriarchal gaze systematically positions feminine bodies as objects and in response women come to live their bodies in such terms.

... the thing I really find threatening and actually frankly annoying is in the swimming pool, there are two Jacuzzis at the side which I never go in ... It is really obvious that men go in there just to sit and ogle the women. (White British female, 60-64)

... when you're in the classes there's a water fountain outside which is next to the weights bit so there's quite a lot of guys come out and just stand there watching the girls queue up for the classes. (White British female, 18-24)

They [referring to other men] usually they watch from the mirror.

Interviewer: From the mirrors?

Okay. So, you can stand in front of the mirrors and then you can see the women behind you? Because the place [the weights area with mirrors] is near some machines, like bicycle machine or running machine. Usually girls are going [on the exercise bikes and running machines] there and they're just watching girls. (White British male, 25-29) 
When challenged about women's rationale for why there is gender segregation within the gym, male interviewees failed to recognise a problem arguing it is 'normal' - thereby implicitly invoking the taken for granted hegemony of heterosexuality (Valentine 1993) for men to look at women in this way. Yet, as Cooper $(2004,96)$ has observed, historically inequality is secured through particular forms of differentiation and segregation being read as 'natural' or 'normal'. In particular, we develop habitual or socially sedimented ways of seeing which mean some dimensions of difference become salient and others less visible or invisible (Al-Saji 2009). In this way, sexism is lived as habit and enacted as embodied everyday practices and through this repetition this particular ordering of difference becomes the norm with the consequence that patriarchy as a power structure which operates in and through particular spaces to systematically (re)produce gender inequalities is obscured. In the following section, we reflect in more detail on the visibility of contemporary sexism.

\section{The visibility of sexism}

The psychologist Gordon Allport $(1954,34)$ who wrote a seminal study of prejudice failed to address the pervasiveness of sexism. Although, he observed that misogynists regard women as inferior, he claimed sexism was rare and that sex was not a ground for prejudice. Yet, historically and cross-culturally women have been regarded as subordinate to men perceived as less intelligent, strong, competent, competitive and so on (cf. Longhurst 1995; Rose 1993). The representation of women as weak, in need of protection and caring is a benevolent form of prejudice, often lacking the blatant aggression of common forms of racism and homophobia (Valentine 2010). Although, the emergence of the women's rights movements in western countries over the last century led to the gradual (albeit uneven) development of gender equality legislation in these societies, nonetheless sexism as a form of prejudice persists.

In the 1980s and 1990s, feminist geography identified occupational segregation by gender (albeit that this process is not stable or consistent), observing the way both essentialist (e.g. about gendered bodily competencies) and moral explanations (about how men and women 'ought' to behave) were used to justify these patterns (e.g. McDowell 1997; Halford and Savage 1998). In this sense, as Morgan (2002, 71) argues, 'gender is a social practice that constantly refers to bodies and what bodies do'.

Our case study research with the Fire and Rescue Service found that traditional stereotypes about men and women's bodily capacities persist. Firefighting is a traditional class-based occupation associated with a hard, physical and heroic masculinity that has allowed firefighters to distance themselves from women and other men employed in 'feminized' office employment (Hall, Hockey, and Robinson 2007). In this context, teamwork is highly valued, producing a culture predicated on male sociability. The gradual entry of women into this occupation has led to a focus on embodiment and specifically the gendered nature of 'natural' capabilities. Some of the male firefighters interviewed reproduced traditional discourses about women's unsuitability for this physically demanding work drawing on what they considered 'common-sense' arguments about embodied differences between men and women which fail to acknowledge the complexity of bodily realities. In particular, a common claim was made that the physical entry standard to the Fire and Rescue Service has been reduced to accommodate women. This, it was claimed, is leading to consequent erosion of the skills and professionalism of the occupation, and placing a greater burden of responsibility on male firefighters to cover for the physical inadequacies of female colleagues. 
She's rubbish [referring to a female colleague]. I'm not being funny. Great person, lovely. Do anything for you. You're not knocking them as people. But they're really not suited to this job, this line of work ... If you say at the end of the day if you were in a house fire with that person and something goes wrong and they've got to drag you out, would they be able to do it, right? There's a lot of people that you would say no, they wouldn't have the ability. They wouldn't have the strength. Maybe they would because the adrenaline is coursing through their veins and stuff like that. But ... you wouldn't want them watching your back if you get me. It's no detriment to them because it's just the way things are, isn't it? It's just nature. Sometimes a female can't physically do a certain physically demanding task. (White British male, 35-39)

They've lowered standard anyway to get females into the job. So they've made the standard easier anyway ... that's okay if there's one person on a watch I suppose because you can make compensations, you're like okay she's never carrying the ladder or whatever, but if there were two or three .... (White British male, 30-34)

The gendering of work is not just a product of the activity undertaken but is evident in the culture of workplaces (McDowell 1997, 2009). Being on watch involves spending time waiting to be called out, time that is often spent in activities to develop fitness and build teamwork (e.g. games of football, volleyball, circuit training). Living together at the station on shift work in such ways results in an intimate knowledge of one another in a bodily way, producing a homo-social culture predicated on banter to overcome the frustration and boredom of waiting (Hall, Hockey, and Robinson 2007). In this context, sexist language and pranks have traditionally been treated part and parcel of normal everyday life with little recognition of the power of language to (re)produce sexual inequalities. Yet, as Sontag $(1973,186)$ has argued, 'language is the most intense and stubborn fortress of sexist assumptions'. It is through the repetition of such behaviours that the fire station has traditionally been produced and stabilised as masculinist space.

Such normative work cultures are increasingly under scrutiny. Notably, Article 13 of the European Union Treaty of Amsterdam - signed by the European Union (EU) member states in 1997 - took effect in 1999. This gave the EU a mandate to require member states to protect citizens from discrimination on the grounds of sex, race or ethnic origin, religion or belief, disability, age or sexual orientation. It contributed to stimulating a rethink of equalities policy in the UK and led to new legislation. While equality legislation had previously been implemented in the UK on race $(1965,1968,1976)$, sex (1975) and disability (1995), the EU directives arising from Article 13 prompted the introduction of the Equality Act (2010) to level up and extend this protection. This legislation requires people to be treated equally in most aspects of public life, regardless of the protected characteristics of age, disability, gender, gender reassignment, marriage and civil partnership, race, religion or belief, sex and sexual orientation. Such equality legislation popularly described as political correctness - is perceived to be redefining spatial normativities about how people should talk and behave in public environments, such as the workplace, de-legitimising certain language, practices and uses of space (Valentine and Harris 2014). The male firefighters acknowledged how they 'ought' to behave even if they do not believe in or accept such normativities, recognising that to do otherwise would be to risk disciplinary action. As such, contemporary sexism is manifest in more subtle ways than traditional gender prejudice. The same habitual ways of thinking persist but these are lived or enacted differently such that they are less obviously visible.

Interviewee: [referring to in the past] we've had one woman ... and she was put in the cage, the hydraulic platform and lifted up and left up there ... there have always been practical jokes, but that's been quashed, as well, which I think sometimes takes the fun out of the job, because it bonds you when you have fun and stuff. Whereas now, it's like you daren't even 
smile at somebody or tell a joke because you might be on a charge or something like that if they take it the wrong way. (White British male, 50-54)

Sometimes I think - I correct other lads sometimes, they've got to watch their Ps and Qs with them [female firefighters] but just to be careful. There's things I wouldn't say in front of you [to female interviewer], I wouldn't say in front of Nina and Carol [two women fire fighters at the station] just because they're women .... (White British male, 45-49)

While the female firefighters interviewed were readily able to recognise blatant forms of sexism, they were less willing or able to identify more subtle forms of sexism. Rather, they commonly denied they experienced gender prejudice, blaming negative experiences on what they rationalised as their own personal shortcomings, such as a lack of confidence or insecurity, as this interviewee describes.

... boys' conversation is very different to girls' conversation in general I think. Sometimes with the Fire Service the sense of humour at the Fire Service is very infantile, stupid ... which I will participate in ... I do like it and I get on really well with men, which is a good job isn't it? But - I do like - I love having banter but sometimes ... When I first joined I was probably less confident and because I was new and didn't really know how things rolled in the Fire Brigade and I would be less - I can remember a few times when I got a bit upset when things went a bit too far. Just with jokey things, I'm not saying it was sexist or anything like that, just having a joke and messing around. (White British female, 40-45)

Denying sexism in this way serves to protect those women who experience it by enabling them to maintain a sense of personal control and to feel they belong in the workplace community. Indeed, some of the women interviewed were themselves complicit with gender prejudice agreeing with male colleagues' views that the standard for entry into the fire service has been lowered since they themselves joined in order to increase the number of female recruits. In such ways, they legitimise traditional gender prejudice yet attempt to protect themselves from its consequences and maintain a privileged position by dis-identifying with other women in the service. In doing so, they risk over-asserting the ability of individual women to actively produce their own lives and underestimate how the ability to enact some identities or realities rather than others is highly contingent on the power-laden spaces in and through which our experiences are lived.

there's quite a lot of women in the fire service now and I know there was a few, a couple that I can think of that had a bit of a hard time. Just because I don't think they were possibly fit enough. So I think some fellows felt they had to carry them. The test that you have to do to get in they changed at one point. I think they were quite a bit easier ... I do think they came in at a lesser level than original women [like herself]. (White British female, 40-45)

The evidence of this section is that despite routine assumptions that there is greater gender equality than ever before, nonetheless sexism persists. Traditional, so-called 'commonsense' arguments about 'natural' embodied gender differences remain a socially sedimented way of seeing. The introduction of workplace equality legislation has contained the expression of blatant gender prejudice (such as the example of locking a woman in a hydraulic cage described in the quotation above) but subtle forms are still evident. Namely, sexist ways of seeing are enacted when women are not present or instantiated through banter - in which women can also become complicit (as a means of survival or as a way of belonging) - which can make it more difficult to name and challenge. In this way, it is potentially becoming more difficult to see patterns of sexism in form and intent. 


\section{Intersecting prejudices: sexism, Islamophobia and classism}

Despite the evidence of the previous section - that sexism persists in everyday life while often remaining unseen - the interviewees who took part in the Lived Experience element of this study sought to represent it as a prejudice which specifically characterises Muslim communities. Phillips (2012) has pointed out - in this journal - that Muslims in western countries are routinely depicted as non-liberal minorities through representations of homophobia, honour killings and forced marriage within their communities. This is particularly evident in media discourses.

In a study of a range of British newspapers, including tabloids, 'middle of the road' papers and broadsheets from across the political spectrum, Meer, Dwyer, and Modood (2010) observed that journalists and commentators frequently depict Islam as a form of cultural coercion which restricts Muslim women's autonomy and means they are unable to assert equal rights claims. In other words, cultural diversity is regarded as the cause of gender and sexual inequalities. Likewise, Ehrkamp's (2010) study of German daily national newspaper articles on forced marriages and honour killings over a period of 10 years (between 1998 and 2008) found that Muslim women were portrayed as having no control over their sexuality. Yet, practices such as forced marriage are not necessarily associated with any religion, and honour killings can be traced to traditional agrarian social and familial organisations rather than to Islamic practice, and are practices not widely endorsed by religious communities (Dustin 2004).

In the British (Khiabany and Williamson 2008; Meer, Dwyer, and Modood 2010) and German media (Ehrkamp 2010), the veil is commonly represented as irreconcilable with gender equality, notwithstanding the fact that, as has been well documented in Gender, Place and Culture and elsewhere, the reasons women in Europe chose to wear the veil are complex (including as a way of dealing with Islamophobia) and differ from those living in countries which insist on it (e.g. Dwyer 1999; Siraj 2011; McGinty 2013). Muslim women are usually portrayed as undifferentiated lacking agency and as victims of what is perceived as a patriarchal and culturally backward Islam - unable to think or act for themselves (Khiabany and Williamson 2008; Meer, Dwyer, and Modood 2010; Ehrkamp 2010).

The visibility of these media discourses were strikingly evident in the Lived Experience element of the research. In reproducing these arguments about the patriarchal nature of Islam, there were, however, subtle gender differences in the ways in which the men and women who took part in the study articulated their views. Women interviewees characterised Islam as misogynistic and as oppressing women - implicitly demonising Muslim men (see also Hopkins 2007a, 2007b, 2009) - without appearing to recognise that gender equality is still some way from being achieved in Europe. In doing so, they were implicitly empathetic towards Muslim women ('I don't think it's fair'; 'you see them ... and they always look really fed up') although they had no direct personal contact with Muslim women and therefore knowledge of their experiences and they were strongly critical of Muslim men ('can't they control themselves?'; 'they look down on women ... they don't think women deserve respect').

I hate it ... covering up, that's one thing. I don't agree with, covering up. I think if I have to wear - especially the one where you have - as my dad calls it, the letterbox ... I don't think it's fair. What is it? Why? I'm still questioning why is it - why is it that men in their culture feel like they wouldn't be able to resist a woman if they saw her legs or whatever it is? Can't they control themselves? So I would question - I would say, why are you wearing that? She'd have to give me a good reason, especially if she's wearing this. I really, really, really don't like it. That's one of my oppositions. I feel quite strongly about it. Especially on gender terms, men should have to wear that if women do. (Black Afro-Caribbean female, 50-54) 
The only kind of groups of people that I ever have had a problem with is Muslims ... because they look down on women. They don't think that women deserve an explanation or respect. You see them going shopping and stuff and you look at them and they always look really fed up. They're always getting shouted at by some bloke in their language ... I've tried to see it from their point of view. But it all just - at the end of the day it all revolves back to the same thing and it's all about control. (White British female, 35-39)

Men who were interviewed also reproduced familiar media discourses about the patriarchal nature of Islam, although their wider biographical interviews often revealed an irony in that their support for gender equality was not always practised in aspects of their own lives. They also articulated their views in more aggressive or hostile language than the women who were interviewed. Here, they moved beyond criticisms of the perceived patriarchal nature of Islam to use the discussion of gender to segue into wider negative discourses (see also Fekete 2006; Hopkins 2007a, 2007b, 2009) about Islam and terrorism and the Government's perceived overindulgence of multiculturalism to justify an end to tolerance (showing no understanding of how such discourses have led to increased harassment and exclusion of both Muslim men and women). In doing so, they were implicitly hostile rather than empathetic towards Muslim women, while using arguments about perceived gender inequality to justify their Islamophobia.

The way they treat women ... Why should your wife be stuck at home tied to the sink? Why should you put a veil around your face? What's that about? Are you that badly disfigured that you need to put it round your face? Maybe I don't understand enough about it but ... I just don't like anything I see about what Muslims do. Making bombs and living amongst us and, all right mate and next thing blowing us up. (White British male, 55-59)

Women are ... treated like second-class citizens. They're treated worse than animals. You see women walking behind the men and to me that - they shouldn't even be here. They're scum, scum of the earth ... I mean they make them wear these stupid gowns ... I don't understand it, I'll be honest. So I don't tolerate them and I think it's wrong ... the Government think we should treat them as equal and I don't because they're not. I mean I'm nothing to shout about and write home about, I've got lots and lots of faults, but I don't treat my wife like a dog ... [later in the interview] ... you've got to be careful what you say. I mean ... I do occasionally go up to them [Muslim women wearing the hijab] and say 'Have you got a bomb under there?' type of thing, but you've got to be careful how you say it .... (White British male, 65-69)

Thus, while the evidence of the previous sections of this paper suggests that sexism is not normally seen by many men, and some women, in their everyday lives because it is a habitual way of being which makes a particular order and meaning of difference the norm, it is seen - albeit erroneously - where it enables the instantiation of different forms of prejudice. In other words, people can see differently - and some meanings and dimensions of difference can become more salient and visible - when they regard their own privileged position as at stake and recognise different ways of mobilising power structures to their own ends.

The complex intersection between different forms of prejudice - and in particular the mobilisation of gender in the service of other forms of negativity and hatred - was also evident in relation to discussions of class. Like Islam, working-class culture in the UK is subject to demonisation in media and political discourse (Haylett 2003; Jones 2012). In particular, moral value judgements about embodiment and ways of living are being used to categorise and define the relative cultural and economic worth of different groups of people with working-class people judged as having the wrong kind of life and culture (Skeggs 2005). Here, classism as a form of prejudice (Valentine and Harris 2014) was commonly expressed by interviewees through popular gendered discourses about 
women's fecundity and excessive femininities in what Skeggs (2005, 967) has characterised as the 'historical-representational moralizing pathologizing, disgustproducing register attached to working-class women'.

When I'm sat on the bus ... it's young girls with push chairs, with two at the side, one in the pram. I think, get a job. How can you afford it? They've just come from McDonald's. I think you're mental. Maybe I'm too house-proud and I won't behave like a tramp, I don't know [edit] This is bad ... it's on the news now. These that are leaving school can't get work, have to get Jobseekers' or dole ... getting bloody pregnant and all the rest of it, getting houses. (White British female, 30-34)

... this street has 40 houses. There's only six houses where there's anybody in full employment. How can the State go on supporting these people? Just as this woman [referring to a neighbour visible through a window], I despise them. They don't know it though. She can't go out to work. She's diabetic, overweight and a host of other problems. She's got a daughter who's just got herself pregnant, who's never worked. She'll be on benefits for the next seven or so years. (Asian British male, 75-79)

A similar gendering of prejudice is also evident in Pulido's (2009) work about immigration politics and motherhood. Here, she also identified the way misogyny is mobilised about pregnant women and those who are already mothers in the service of prejudice towards migrants, which she observes resonates with the hateful depictions of African-American women as 'welfare mothers' dating back to the 1960s.

As such, this section demonstrates the need to explore the ways that sexism as a form of prejudice is racialised, and classed, and consequently the complex ways in which debates about gender equality and femininities can therefore be mobilised to justify and reinforce negative attitudes towards, and in some cases the discriminatory treatment of, other groups. By making visible the intersectional nature of prejudices in this way, we might shed further light on the complex power relations which constitute society and space.

\section{Conclusion: seeing differently}

Recent developments in feminism have stressed the relational, differentiated and contested nature of gender as evidenced by the rich body of research published in Gender, Place and Culture over the last 21 years. This has led to the rejection of the unified category women, and with this the right for feminism to make claims on behalf of all women. As a result, while much of the work published in this journal is fundamentally about gender inequalities, we rarely name the negative treatment of women as sexism in academic research. An unintended consequence of this is that patriarchy as a form of power relations has become relatively neglected and hidden. Yet, while our identities as individuals might be multiple and fluid, power continues to operate in and through the spaces within which we live and move in systematic ways to generate hegemonic cultures that marginalise or exclude women. Certainly, the evidence of this research is that sexism remains a persistent form of prejudice.

While women have unimaginable liberty compared to previous generations, habitual or socially sedimented ways of seeing have developed over time (Al-Saji 2009) which mean that in everyday life patterns of gender differentiation and segregation have come to be read as 'natural' or normalised: the product of modes of embodiment, and in this sense Charlotte Bunch's observation that the fundamental basis of feminism is the body, with which we introduced this paper, remains as true today as 20 years ago. Consequently, gender as a dimension of difference has become less socially visible (although not necessarily to those who experience its effects personally). While, the development of 
equality legislation has contained the public expression of the most blatant forms of gender prejudice, sexism persists and is manifest in subtle ways. Indeed, women are often complicit in its reproduction. As a consequence, it can be difficult to name and challenge, thus making it hard to identify contemporary patterns of sexism in form and intent with the effect that patriarchy as a power structure which systematically (re)produces gender inequalities, is obscured by its ordinariness.

Rather, sexism appears only to be 'seen' - and even then in spurious and paradoxical ways - when it affords the instantiation of other forms of prejudice, such as Islamophobia and class prejudice. In other words, it is made visible when the recognition of sexism can be mobilised, not to question the legitimacy of patriarchy as a social structure, but instead in the service of other forms of power. Moreover, in doing so the evidence of this paper is that sexism can also be instantiated to demonise some groups of men (e.g. Muslims). Contrary to the determinism of some previous ways of thinking about power which often classified individuals into fixed categories as oppressed or oppressor, women can be complicit in sexism and men can experience its consequences.

As such, a challenge for Gender, Place and Culture going forward is to make sexism more visible as a particular form of prejudice while also exposing the complexity and fluidity of its relationship to other forms of oppression and social categories. In other words, we need to be watchful of the way particular orderings of difference can become taken for granted, or socially sedimented in such a way that we cease to pay sufficient attention to how they operate. Rather, we need to constantly question our ways of seeing if we are to recognise our habitual ways of being and to challenge and transform the normative and complexly intersectional nature of power relations.

\section{Acknowledgements}

We would like to thank Ulrike Vieten for encouraging us to read the article by Alia Al-Saji, which inspired the argument of the paper, and the anonymous referees for their helpful comments.

\section{Funding}

We are grateful to the European Research Council which funded this research through an Advanced Investigator Award [grant agreement number 249658] awarded to Gill Valentine entitled Living with Difference in Europe: Making Communities Out of Strangers in an Era of Supermobility and Superdiversity.

\section{Notes on contributors}

Gill Valentine is a professor in human geography at the University of Sheffield, UK, where she is also Pro-Vice Chancellor for the Faculty of Social Science. Gill's research interests include: social identities and belonging; childhood, parenting and family life; and urban cultures of consumption. She is currently leading a European Research Council programme of research titled Living with Difference. She has (co)authored/edited 15 books and over 100 journal articles.

Lucy Jackson is a postdoctoral research associate with the University of Sheffield's ERC funded project LIVEDIFFERENCE. Lucy's doctoral research, awarded in 2012, investigated the emotional and lived experience of citizenship for female migrants in South Wales and Singapore. Lucy's research interests are in the negotiation of difference and identity, and the emotions implicit in this. Her current research is on competing rights and groups in conflict. Lucy is a member of the Gender and Feminist Geography Research Group and is a committee member for the Social and Cultural Geography Research Group of the RGS-IBG.

Lucy Mayblin is a postdoctoral research associate working on the European Research Council funded project Living with Difference in the Department of Geography at the University of 
Sheffield, UK. She was awarded her PhD in 2013. This ESRC funded doctoral research took a historical institutionalist perspective in analysing current British asylum and refugee policy. Lucy is co-convenor of the British Sociological Association's Comparative and Historical Study Group, and a member of the editorial board for the journal Studies in Social and Political Thought.

\section{References}

Allport, Gordon. 1954. The Nature of Prejudice. Reading, MA: Addison-Wesley.

Al-Saji, Alia. 2009. "A Phenomenology of Critical-Ethical Vision: Merleau-Ponty, Bergson and the Question of Seeing Differently." Chiasmi International 11: 375-398.

Anderson, Kay. 1991. Vancouver's Chinatown: Racial Discourse in Canada 1875-1980. Montreal: McGill-Queen's University Press.

Bailey, Marlon, and Rashad Shabazz. 2013. "Gender and Sexual Geographies of Blackness: AntiBlack Heterotopias (Part 1)." Gender, Place and Culture 21: 316-321. doi:10.1080/0966369X. 2013.781305.

Bartky, Sandra. 1990. Femininity and Domination: Studies in the Phenomenology of Oppression. London: Routledge.

Bondi, Liz, and Damaris Rose. 2003. "Constructing Gender, Constructing the Urban: A Review of Anglo-American Feminist Urban Geography." Gender, Place and Culture 10: 229-245.

Bunch, Charlotte. 1995. "Transforming Human Rights from a Feminist Perspective.” In Women's Rights/Human Rights: International Feminist Perspectives, edited by Julie Peters, and Andrea Wolper, 11-17. London: Routledge.

Cooper, Davina. 2004. Challenging Diversity - Rethinking Equality and the Value of Difference. Cambridge: University of Cambridge Press.

Crenshaw, Kimberle. 1989. "Demarginalizing the Intersection of Race and Class. A Black Feminist Critique of Antidiscrimination Doctrine." University of Chicago Legal Forum 139-167.

Dustin, Moira. 2004. Gender Equality and Cultural Diversity. London: Nuffield Foundation.

Dwyer, Claire. 1999. "Veiled Meanings: Young British Muslim Women and the Negotiation of Difference." Gender, Place and Culture 6: 5-26.

Ehrkamp, Patricia. 2010. "The Limits of Multicultural Tolerance? Liberal Democracy and Media Portrayals of Muslim Migrant Women in Germany." Space \& Polity 14: 13-31.

Fekete, Liz. 2006. "Enlightened Fundamentalism? Immigration, Feminism and the Right." Race \& Class 48: 1-22.

Foucault, Michel. 1977. Discipline and Punish: The Birth of the Prison. London: Allen Lane.

Halford, Susan, and Mike Savage. 1998. "Rethinking Restructuring: Embodiment, Agency and Identity in Organisational Change." In Geographies of Economies, edited by Roger Lee, and Jane Wills, 373-405. London: Arnold.

Hall, Alex, Jenny Hockey, and Victoria Robinson. 2007. "Occupational Culture and the Embodiment of Masculinity: Hairdressing, Estate Agency and Firefighting." Gender, Work and Organisation 14: 534-551.

Hansen, Susan, and Geraldine Pratt. 1995. Gender, Work and Space. London: Routledge.

Haylett, Chris. 2003. "Culture, Class and Urban Policy: Reconsidering Equality." Antipode 35: $55-73$.

Holloway, Sarah L., Gill Valentine, and Mark Jayne. 2009. "Masculinities, Femininities and the Geographies of Public and Private Drinking Landscapes." Geoforum 40: 821-831.

Hopkins, Peter. 2007a. "Young Muslim Men's Experiences of Local Landscapes after 11 September 2001." In Geographies of Muslim Identities: Diaspora, Gender and Belonging, edited by Cara Aitchison, Peter Hopkins, and Mei-Po Kwan, 189-200. Aldershot: Ashgate.

Hopkins, Peter. 2007b. "Global Events, National Politics, Local Lives: Young Muslim Men in Scotland." Environment and Planning A 39: 1119-1133.

Hopkins, Peter. 2009. "Responding to the Crisis of Masculinity: The Perspectives of Young Muslim Men from Glasgow and Edinburgh." Gender, Place and Culture 16: 299-312.

Johnson, Louise C. 1994. "What Future for Feminist Geography." Gender, Place and Culture 1 (1): $103-113$.

Johnson, Louise C. 2013. "Feminist Geography 30 Years on - They Came, They Saw but Did They Conquer?" Geographical Research 50: 345-355. 
Johnston, Lynda. 1996. "Flexing Femininity: Female Body-Builders Refiguring 'The Body'." Gender, Place and Culture 3 (3): 327-340.

Jones, Owen. 2012. Chavs: The Demonisation of the Working Class. London: Verso.

Khiabany, Gholam, and Milly Williamson. 2008. "Veiled Bodies - Naked Racism: Culture, Politics and Race in The Sun." Race and Class 2: 69-88.

Koskela, Hille. 1997. "'Bold Walk and Breakings': Women's Spatial Confidence versus Fear of Violence." Gender, Place and Culture 4: 301-320.

Longhurst, Robyn. 1995. "The Body and Geography." Gender, Place and Culture 2 (1): 97-105.

Macleavy, Julie. 2007. "Engendering New Labour's Workfarist Regime: Exploring the Intersection of Welfare State Restructuring and Labour Market Policies in the UK." Gender, Place and Culture 14: 721-743.

McDowell, Linda. 1983. "Towards and Understanding of the Gender Division of Urban Space." Environment and Planning D: Society and Space 1: 59-72.

McDowell, Linda. 1997. Capital Culture: Gender at Work in the City. Oxford: Blackwell.

McDowell, Linda. 2009. Working Bodies: Interactive Service Employment and Workplace Identities. Oxford: Wiley-Blackwell.

McGinty, Anna Mansson. 2013. "Emotional Geographies of Veiling: The Meanings of the hijab for 5 Palestinian American Muslim Women." Gender, Place and Culture. doi:10.1080/0966369X. 2013.810601.

Mclean, Jessica, and Sophia Maalsen. 2013. "Destroying the Joint and Dying of Shame? A Geography of Revitalised Feminism in Social Media and Beyond." Geographical Research 51: $242-256$.

Meer, Nasar, Claire Dwyer, and Tariq Modood. 2010. "Embodying Nationhood? Conceptions of British National Identity, Citizenship and Gender in the 'Veil Affair'." The Sociological Review 58: 84-111.

Morgan, David. 2002. "You Too Can Have a Body like Mine." In Gender: A Sociological Reader, edited by Stevi Jackson, and Sue Scott, 406-422. London: Routledge.

Muller, Tiffany. 2007. "Liberty for All? Contested Spaces of Lesbian Resistance." Gender, Place and Culture 14: 197-213.

Pain, Rachel. 1991. "Space, Sexual Violence and Social Control: Integrating Geographical and Feminist Analyses of Women's Fear of Crime." Progress in Human Geography 15: 415-431.

Phillips, Richard. 2012. "Interventions against Forced Marriage: Contesting Hegemonic Narratives and Minority Practices in Europe." Gender, Place and Culture: A Journal of Feminist Geography 19: 21-41.

Pulido, Laura. 2009. "Immigration Politics and Motherhood." Amerasia Journal 35: 168-178.

Rose, Gillian. 1993. Feminism and Geography: The Limits of Geographical Knowledge. Cambridge: Polity Press.

Siraj, Asifa. 2011. "Meanings of Modesty and the Hijab amongst Muslim Women in Glasgow, Scotland." Gender, Place and Culture 18: 216-231.

Sontag, Susan. 1973. "The Third World of Women.” Partisan Review 40: 186-199.

Skeggs, Beverly. 2005. "The Making of Class and Gender through Visualising Moral Subject Formation.” Sociology 39 (5): 965-982.

Staeheli, Lynn, and Richa Nager. 2002. "Feminists Talking across Worlds." Gender, Place and Culture 9: 167-172.

Valentine, Gill. 1989. "The Geography of Women's Fear.” Area 21: 385-390.

Valentine, Gill. 1992. "Images of Danger: Women's Sources of Information about the Spatial Distribution of Male Violence." Area 24: 22-29.

Valentine, Gill. 1993. "(Hetero)sexing Space: Lesbian Perceptions and Experiences of Everyday Spaces." Environment \& Planning D: Society \& Space 11: 395-413.

Valentine, Gill. 2007. "Theorising and Researching Intersectionality: A Challenge for Feminist Geography." Professional Geographer 59: 10-21.

Valentine, Gill. 2008. "Living with Difference: Reflections on Geographies of Encounter." Progress in Human Geography 32: 321-335.

Valentine, Gill. 2010. "Prejudice: Rethinking Geographies of Oppression.” Social \& Cultural Geography 11: 521-537.

Valentine, Gill, and Catherine Harris. 2014. "Strivers v Skivers: Class Prejudice and the Demonisation of Dependency in Everyday Life." Geoforum 53: 84-92. 
Women and Geography Study Group (WGSG). 1984. Geography and Gender: An Introduction to Feminist Geography. London: Hutchinson.

Young, Iris Marion. 1990. Throwing Like a Girl and Other Essays in Feminist Philosophy and Social Theory. Bloomington: Indiana University Press.

\section{ABSTRACT TRANSLATIONS \\ 21 años de Gender, Place and Culture: modos de ver: el sexismo y el prejuicio olvidado}

Los avances recientes en el feminismo, descriptos en Gender, Place and Culture a lo largo de los últimos 21 años, han enfatizado la naturaleza relacional, diferenciada y disputada del género. Esto ha conducido al rechazo de la categoría unificada de la mujer, y con esto al derecho del feminismo para hacer reclamos que de parte de todas las mujeres. Este trabajo sostiene que una consecuencia no buscada de esta evolución de las formas de pensar sobre el género es que el patriarcado como una forma de relaciones de poder ha quedado relativamente olvidado. Se basa en la investigación de un proyecto del Consejo Europeo de Investigación (que incluye entrevistas biográficas y estudios de caso de un gimnasio y un lugar de trabajo) para demostrar que mientras el desarrollo de la legislación igualitaria ha restringido la expresión pública de las formas más flagrantes del prejuicio de género, el sexismo persiste y se manifiesta en formas sutiles. Como consecuencia, puede ser difícil de nombrar y desafiar, con el efecto de que el patriarcado como estructura de poder que sistemáticamente (re)produce desigualdades de género se oculta por su carácter ordinario. En cambio, el sexismo parece solo ser "visto" cuando permite la ejemplificación de otras formas de prejuicio, tales como la islamofobia. De esta forma, sostenemos que de cara al futuro, Gender, Place and Culture tiene la responsabilidad de hacer que el sexismo sea más visible como una forma particular de prejuicio, a la vez que revelar la complejidad y fluidez de sus relaciones interseccionales con otros modos de opresión y categorías sociales.

Palabras claves: género; sexismo; prejuicio; intersección; ver de modo diferente; patriarcado

\section{性别、地方与文化二十一载 : 观看的方式 : 性别歧视作为被遗忘的偏见}

过去二十一年来, 《性别、地方与文化》期刊, 载明了晚近女性主义的发展。该 发展强调性别的关係性、差异化与争夺的本质, 导致了拒绝女性做为一个统一的 范畴, 以及女性主义代替全体女性发声的权力。本文主张, 该发展导致了思考性 别的方式中一个非预期性的后果, 即父权制度作为一种权力关係的形式, 相对地 受到忽略。本文运用一项欧洲研究委员会计画的研究 (包括传记式访谈, 以及健 身中心和工作场所的案例研究), 证明平等立法的发展, 虽然遏止了最为露骨的 性别偏见形式的公共表态, 但性别偏见仍然存在, 并且以隐晦的方式表露。因 此, 父权体制做为系统性 (再) 生产性别不平等的权力结构, 被其平凡性所遮 掩, 使得指认与挑战父权体制变得困难。更确切而言, 性别歧视似乎只有在为其 他形式的偏见提供例证时，例如伊斯兰恐惧症，才得以被“看见”。我们据此主张，

《性别、地方与文化》有责任进一步让作为 - 种特定歧视形式的性别歧视更能被 看见, 并同时揭露性别歧视与其他形式的压迫及社会范畴多元交织关係的复杂性 与流动性。

关键词：性别; 性别歧视; 偏见; 多元交织; 不同的观看方式; 父权体制 